\title{
Organization as a Key to Police Effectiveness*
}

\section{Robert EdWARd Mitchell}

Director, Social Survey Research Center, The Chinese University of Hong Kong; Research Sociologist, Survey Research Center, University of California Project Assistant, 1956-59, Project Director, 1959-62, Bureau of Applied Social Research, Columbia University; Coordinator of International Research Program, Survey Research Center, University of California, Berkeley, 1962-66 B.A. (Oriental Civilizations), 1952, University of Michigan; M.A. (China Area Program), 1955, Harvard University; Ph.D. (Sociology), 1962, Columbia University

Citing evidence on intercity differences in crime rates, as well as differences in rates of increase for several kinds of crime, this paper argues that police departments differ in their effectiveness. The key to an understanding of effectiveness lies in the way police departments themselves are organized. How individual policemen perform their occupational duties depends in part on how. these duties are defined. In order to understand these definitions and the pressures which affect the way police perform their work, it is necessary to adopt a "systemic" view of legal and illegal forces in society. Determinants of police effectiveness are explored, through examples from the control of organized crimes, by relating the way departments interact with other legal and illegal organizations.

$\mathbf{S}^{\mathrm{s}}$ EVERAL COMPÈTING THEORIES Of crime control have been given increasing public and legislative attention in the past few years. Many citizens who cry out against "crime in the streets" advocate solving the problem by increasing the number and power of police and by punishing offenders more severely: On the other hand, many social workers and social scientists would initiate mammoth programs designed to bring about the Great Society, thus removing the social causes of crime.

Both of these approaches overlook

\footnotetext{
- Publication A-67, Survey Research Center, University of California, Berkeley.
}

the organizational dimension of police departments as a factor determining the effectiveness of law enforcement efforts to eliminate organized crime. One approach adheres to a beehive perspective of police departments: every department in every city has the same form of organization, and the only way to increase the sting and the honey is to add more bees. Advocates of the other approach are concerned with the dangers of a police state and the use of police departments as tools by unscrupulous politicians.

Police departments must be put in a new, unbiased perspective if progress is to be made either in understanding or in controlling organized crime. It 
is especially important to realize that departments differ in their operations and that they are capable of dramatically altering the extent to which they are effective in the fight against crime. Concern with the internal organization of departments and with the relationship between departments and the organizational environments in which they operate is crucial in obtaining this new perspective.

One cannot examine police effectiveness independently of criminals, city governments, courts, and others with whom the police have an occupational concern. In America the significance of the police derives to a considerable extent from the magnitude of crime. About two million major crimes a year are reported, and the value of stolen property is estimated at $\$ 600$ million. It seems reasonable to predict that the crime problem will become even more serious in the future. It is said, for example, that crime is increasing five times faster than the population.

The growth of lawlessness is not, however, a unique American phenomenon. In England and Wales, the number of "persons found guilty of indictable offenses" per 100,000 population increased from 502 in 1955 to 747 in 1960. In Sweden, "crimes known to the police," standardized for the size of population, have also shown an increase over the years.

Crime-reporting procedures vary so greatly from one country to the next that international comparisons of crime rates are not reliable. Nevertheless, current information-admittedly inadequate-suggests the dismal hypothesis that societies have a normal rate of crime. This rate, it seems, is predicted by a nation's level of industrialization, so that we can look in the future to an ever increasing crime problem in all societies around the world.

If this prophecy is reasonably accurate, the police will play an increasingly important role in society. This role need not be one of strategic ham. lets in which precinct stations serve as control centers in the war against a hostile, lawless countryside. Two sets of statistics, neither one of which is guaranteed to be accurate, suggest that the police are able, when properly organized, to influence the rate at which crime rates will increase or decrease.

First, some types of crime are increasing more slowly than others, and a few rates are actually decreasing. Table 1 presents the arrest rates for three examples of organized crime, each of which is, when compared with most other types of crime, relatively easy to control by energetic and effective police action. In the ten-year period $1950-60$, the arrest rate for violations of narcotic and drug laws more than doubled. In contrast, the arrest rate for prostitution and commercialized vice was almost halved, and arrests for gambling also decreased. These figures do not mean that police departments are becoming less concerned with organized crime or that the gap is widening between arrest rates and rates at which these crimes are actually committed in the population at large. Rather, in part, the lower rates probably reflect increased effectiveness in performance of police duties.

Second, crime rates vary sharply from city to city. These differences suggest either that police departments in some cities are more effective than others or that they differ widely in what they consider a crime. In any event, they suggest that departments differ greatly in performance and, in- 
TABLE 1

Arrest Rate (Number of Arrests Per 100,000 Population) for Three Types of Organized Crime

\begin{tabular}{|c|c|c|c|}
\hline Type of Crime & 1950 & 1960 & Ten-Year Difference \\
\hline $\begin{array}{l}\text { Narcotic and Drug Law Violations } \\
\text { Prostitution and Commercialized Vice } \\
\text { Gambling }\end{array}$ & $\begin{array}{r}10.2 \\
41.4 \\
138.7\end{array}$ & $\begin{array}{r}25.5 \\
24.3 \\
113.0\end{array}$ & $\begin{array}{r}15.3 \\
-17.1 \\
-25.7\end{array}$ \\
\hline
\end{tabular}

- Figures obtained from Uniform Crime Reports for the United States, 1950, 1960.

ferentially, in their ability to control and eliminate crime. Table 2 presents differences in crime rates between cities of approximately the same size within the same state. The size factor is a crude statistical control for the complex of factors that tend to produce criminal activity, and the state factor is a crude statistical control for differences in legal definitions of crime. Overall, the difference in crime rates for paired cities is quite startling.

Police departments are differentiated in several other ways. In California, for example, the Oakland and San Francisco departments are considered by many to have a better relationship with minority groups than does Los Angeles. In dealing with civil liberties, some departments have been known to tolerate overzealous search and seizure procedures, practices which invite the federal courts to enter into the administration of criminal justice at the local level (see Mapp v. Ohio, 367 U.S. 643 [1961]). More generally, some departmentsfor example, Milwaukee and Los Angeles - have national reputations today for being "clean" departments, while others - for example, Chicago and Boston-suffer from poor reputations. These reputations refer to the amount of police corruption and inefficiency, which are themselves partly responsible for the crime problem.

In the last ten years a great number of examples of police-criminal collu- sion have come to the public's attention. A partial list of departments with kmown unsavory incidents would include Baltimore, Burlington (Vt.), Chicago, Denver, Detroit, Hudson County (N.J.), Los Angeles, Miami, Nashville, New York, New Orleans, Omaha, San Francisco, Tulsa, and

TABLE 2

Crime Rate (Crimes Reported" per 100,000 Population) for Selected Cities, 1956

\begin{tabular}{|c|c|c|}
\hline Cities & Population & Crime Rate \\
\hline $\begin{array}{l}\text { Illinois } \\
\text { Peoria } \\
\text { Rockford }\end{array}$ & $\begin{array}{l}113,000 \\
119,000\end{array}$ & $\begin{array}{l}2,290 \\
1,063\end{array}$ \\
\hline $\begin{array}{l}\text { Ohio } \\
\text { Cincinnati } \\
\text { Columbus }\end{array}$ & $\begin{array}{l}522,000 \\
431,000\end{array}$ & $\begin{array}{r}1,320 \\
610\end{array}$ \\
\hline $\begin{array}{l}\text { Massachusetts } \\
\text { New Bedford } \\
\text { Cambridge }\end{array}$ & $\begin{array}{l}110,000 \\
113,000\end{array}$ & $\begin{array}{r}1,750 \\
858\end{array}$ \\
\hline $\begin{array}{l}\text { Michigan } \\
\text { Flint } \\
\text { Grand Rapids }\end{array}$ & $\begin{array}{l}195,000 \\
200,000\end{array}$ & $\begin{array}{l}3,015 \\
1,683\end{array}$ \\
\hline $\begin{array}{l}\text { California } \\
\text { Oakland } \\
\text { San Diego }\end{array}$ & $\begin{array}{l}455,000 \\
468,000\end{array}$ & $\begin{array}{l}3,010 \\
1,790\end{array}$ \\
\hline $\begin{array}{l}\text { Connecticut } \\
\text { Hartford } \\
\text { Bridgeport }\end{array}$ & $\begin{array}{l}186,000 \\
175,000\end{array}$ & $\begin{array}{r}1,525 \\
998\end{array}$ \\
\hline $\begin{array}{l}\text { Oklahoma } \\
\text { Oklahoma City } \\
\text { Tulsa }\end{array}$ & $\begin{array}{l}285,000 \\
239,000\end{array}$ & $\begin{array}{l}2,690 \\
2,038\end{array}$ \\
\hline
\end{tabular}

"These are "Part I" crimes_criminal homicide, rape, robbery, aggravated assault, burglary, larceny, and auto theft.

bVernon L. Hoy, "The Police Specialist in District Stations" (M.Sc. Pub. Adm. thesis, University of Southern California, School of Public Administration, June 1958), pp. 85-90. 
Washington, D.C.-cities in every region of the country.

Some departments are, as Suther. land put it, "systematically lawless." "This does not mean," he noted, "that every policeman is lawless, but that as a system the police operate in a lawless manner." Police graft is a good example of systematic lawlessness.

Royal Commission studies in England, as well as many local, state, and national studies in America, have documented such lawlessness as proof of the existence of organized criminal groups. In such instances, the criminal world tends to control the overall performance of entire police departments. However, there is considerable evidence that departments are able to change for the better. In many cities the police, for some as yet unknown reason, have been able to drastically reduce incidents of organized crimes. Prostitution, gambling, and narcotics seem to be especially amenable to police control.

\section{Police Operations}

The few social scientists who have studied the police have focused almost exclusively upon the situation of the individual policeman. By doing so, they overlook the organizational dimension of crime control, a perspective that can be approached primarily through a comparative study of departments. A narrow concern with the individual policeman can also lead to erroneous findings of what are thought to be unique hazards. For example, one study claimed that feelings of inadequate public recognition and even outright community disrespect contributed to the policeman's proclivity to employ unwarranted force in the performance of his tasks. 1 Of course, other studies have found that al- though ministers and college professors also feel they are not given adequate community recognition, these feelings do not lead them to any noticeable misuse of their position to manipulate parishioners and students. ${ }^{2}$ Furthermore, there is no evidence to date that differences in the use of force by individual policemen, or departmental differences in the use of force, are in any way related to differences in felt deprivation on the part of individual policemen. Although a study of the individual policeman is not without value, the limitations of this perspective deserve notice.

A concern with police systems also has its limitations, but it can lead to a better understanding of a department's effectiveness in its program against organized crime. Specifically, if we consider effectiveness not only as a significant and measurable concept but also as a characteristic of organizations rather than of individuals, a number of social science approaches to the study of organizations can be adopted to throw new light on police systems. For example, it is possible to study how departments which differ in internal organization, as well as in their relations to various community groups, also differ in their ability to control organized crime. Although such studies have not actually been conducted, some scattered evidence indicates the value of such an organizational or "systemic" approach to po lice operations.

1 William A. Westley, "Violence and the Police," American Journal of Sociology, July 1953, pp. 34-41.

2 Robert Edward Mitchell, "When Ministers and Their Parishioners Have Different Class Positions," Review of Religious Research, Fall 1965, pp. 28-41. 
Inside Police Departments

A fairly large though dull corpus of literature has been compiled on how to reduce costs and allocate resources within police departments. It includes a folklore on how to keep police systems healthy and effective, making unfounded assertions that relate salaries, vacations, promotions, and swing shifts to the morale of de. partments.

Such conjectures refer to an entire police department, but the major responsibility for the control of organized crime rests heavily on certain special groups within the department, especially vice squads, detective bureaus, and intelligence units. These typically are élite groups: their salary scales are higher, they recruit the more able men, their responsibilities are intellectually more demanding, and they are able to work in mufti. Yet in many cities these élite elements have not been notably successful against organized crime. In fact, since vice squads often desert to the enemy, a closer scrutiny of them may provide hints on how to organize police departments for a more effective offense against organized crime.

Vice squads are organized in a number of different ways. In some cities their functions are distributed throughout the force; in others, there is a strict division of labor, including constraints on what patrolmen and detectives can do in vice cases. In some instances the squad concerns itself with juvenile vice, while in others this is primarily the responsibility of special juvenile officers. Some vice squads have special narcotics and other details. Some rotate their members so that continually new, relatively unsullied men are charged with the often undesirable, tempting work. In some large departments the squad operates out of a central headquarters; in others the vice squad work is divided into multipurpose details, each of which operates out of a local precinct.

These variations have developed as means to control not only criminals but also police. However, despite local claims made for particular variations, no systematic information has ever been marshaled to prove that any one organizational pattern is more effective than another. Furthermore, it is unlikely that any such assessment of effectiveness can be made without first placing departments within the larger context of their operation.

A major key to effectiveness is found in the external challenges and obstacles to law enforcement, for these help define both the goals of police departments and the means available to them. How are departments affected by the general community, other legal agencies, political and civil authorities, and the criminal world itself?

\section{The Community}

Police in many communities have ample reason to complain about the public's failure to assist them in preventing avoidable crime. People are murdered and robbed because of their neighbors' apathy, and criminals are let free because witnesses to their crime refuse to "get involved." Such attitudes certainly make it harder for the police to perform their work effectively. They also suggest that fiction and myth surround the role assigned to police in American society. The police picture themselves as operating under conditions similar to those in England, while, in fact, the American public has a continental perspective of law enforcement. The distinction be- 
tween these systems was recently drawn by a Royal Commission which referred to a fundamental contrast "between the Continental principle of placing responsibility for the maintenance of law and order upon the executive government and arming it with powers of direct enforcement, and the British principle that it is the right and duty of each citizen to preserve the peace and bring the malefactors to justice, with its corollary that the police are merely paid to act on the citizen's behalf."

The contrast on this view is seen in small things and big things alike: the British police are unarmed, but most policemen on the Continent carry arms; and political and secret police appear to flourish on the Continent, for their role as agents of the state leaves them a prey to political extremists. ${ }^{3}$

A number of recent legal measures have been designed to swing the American population over from the Continental to the British pattern. For example, some Good Samaritan bills hold a citizen liable to legal prosecution for failing to comply with a policeman's request for assistance. If such legislation is successful, perhaps it will make deputies of us all and thereby place the public on a par with the police in a situation similar to that which legally exists in England, where, in the view of the common law, a policeman is only "a person paid to perform, as a matter of duty, acts which if he were so minded he might have done voluntarily."4

However, the history of guerrilla warfare teaches us that it is not easy to transform a hostile peasantry into informers and collaborators. After all,

\footnotetext{
3 Royal Commission on the Police, Final Report (London: H.M.S.O., 1962) .

+ Ibid.
}

the police are not spearheading a revolutionary attack on society, and their work does not have a visible impact on the economic, political, and social welfare of the population. Therefore, the effect of this moralistic approach to the crime problem is questionable. Nevertheless, its possible benefits should not be neglected. Certainly, studies should be conducted on how these Good Samaritan laws affect the public's attitudes and the effectiveness of police departments.

\section{OTher Legal AND Quasi-legal SYSTEMS}

Local police departments operate within and are affected by a system of legal agencies. The federal government has treasury, narcotics, Internal Revenue, and postal police groups as well as the FBI; the state, the county, and the local community often have comparable groups, including quasiofficial crime commissions, and, of course, district attorneys. In addition to these law enforcement agencies, there is also the court system, including judges, lawyers, bondsmen, and the like.

Courts have a singularly important impact on the operation and effectiveness of departments, for they are the major mechanisms serving to control the police. They help define the law by the evidence they admit, the proportion of defendants they convict and sentence, and the severity of the judgments they hand down-actions which reward and punish police behavior and thereby help the policeman define and enforce the law. The important implications of these processes for the police are seen perhaps most clearly in the English experience with a 1948 bill on juvenile first offenders, which resulted in a 60 per cent drop 
in the number of juveniles sent to prison. Investigations related to such First Offender bills revealed a wide diversity among the thousand or so magistrate courts in England. Some courts committed to prison as little as 8 per cent of the accused; others, as much as 40 per cent." While these figures may reflect differences in police departments and public prosecutors, as well as in the courts, they also sug. gest that departments differ in their experiences with the courts and that police behavior that is rewarded in one community is punished in another.

My informal interviews with American lawyers indicate that these same problems occur here and are seriously' aggravated by the political appointment of often unqualified men to the bench. An unprofessional court system amenable to political pressure results in practices which discourage and demoralize police departments: judges issue "quickie" writs releasing offenders "with connections," they throw cases out of court, and in some communities they publicly chastise the arresting police officers. The lawyers suggested that police officers soon learn it is useless to arrest certain criminals or to crack down on certain types of crime.

In many communities police departments can become effective only if the courts are first reformed. California's Special Crime Study Commission on Organized Crime forcefully made this same point in 1950.' The Commission also noted that "there are about 75 police, justices, and municipal courts or departments thereof in Los Angeles

\footnotetext{
Ibid.

6 California Special Crime Study Commission on Organized Crime. Third Progress Report, 1950.
}

County with criminal jurisdiction." For the most part, they are completely independent units with "almost as many interpretations of the criminal laws as there are judges." This proliferation of satellite cities within a single metropolitan area ${ }^{7}$ increases the likelihood that organized criminal elements will be able to locate at least one safe haven from which to manage their affairs in the larger area. In such areas, it is not enough to reform one community; all of them need attention.

Therefore, the effectiveness of po. lice departments seems to be affected by the operation of the courts-by the proportion of all police arrests that eventually result in conviction, the quality of sentencing, the court records on specific offenses, the types of evidence admitted, the record on writs of habeas corpus, practices regarding first offenders, and the like. Effectiveness may also be influenced by the typical operations of lawyers, bondsmen, parole officers, district attorneys, and others who are involved in the administration of criminal justice and therefore impinge on and affect the performance of police tasks.

\section{Political Parties and Local GOVERNMENTS}

Police departments, as well as the courts, have to be considered in the still wider perspective of the communities in which they operate and the people who appoint and pay them. Earlier journalistic critiques of the police were typically placed within this larger framework, and charges

7 Los Angeles County had forty-six separate law enforcement agencies in 1950, and Chicago had more than four hundred independ. ent police forces within fifty miles of thc center of the city. 
were made that political parties and city governments subverted the performance and effectiveness of police departments. In this connection Sutherland noted that "Formally, the police department is organized to operate for the welfare of society; informally, it is organized for the welfare of the politicians." 8 Since the politicians are assumed to have considerable influence on the courts and upon government administration, and since it is also often assumed that politicians are influenced by criminal elements in the community, it seems likely that the effectiveness of the police is related to the ethical standards and practices of politicians and public servants. This relationship was noted in 1894-95 by the Lexow Committee in New York City, where it was found that the same system of bribery used by criminals was also used by commission merchants, contractors, pushcart vendors, and bootblacks who wanted to use the public streets for private business. In other words, the police alone were not corrupt; corruption characterized the entire governmental system. There is no reason to suppose that this characterization is not applicable today. A report by the California Crime Study Commission in 1949 indicated that "it is common practice of slot machine operators throughout the country to pay 10 per cent to 20 per cent of their gross profit for protection and graft. . . $\$ 400,000,000$ is being spent annually by the slot machine racketeers for bribery and corruption of public executive officers." 9

8 Edwin H. Sutherland, Principles of Criminology, 5th ed. (Philadelphia: J. B. Lippincott, 1955).

9 California Special Crime Study Commission on Organized Crime, Second Progress Report, 1949.
All criminals are more or less dependent upon their social contacts with more respectable members of society and this is particularly true of those engaged in commercial forms of crime. For them, friendship with political figures is absolutely essential. In no other way can the criminal groups and syndicates obtain that immunity from interference by law enforcement agencies which is just as essential to successful gang operations as the discipline imposed by acts of violence. ${ }^{10}$

\section{The World of Organized Crime}

Some cynics would debate whether criminals are more deplorable and antisocial than police departments and city halls. Certainly many observers would agree with William Foote Whyte's assertion that "the primary function of the police department is not the enforcement of the law but the regulation of illegal activities." 11 Numerous crime investigations as well as Whyte's study of Cornerville support this claim. Furthermore, they suggest that crime, like the police, can be viewed as a system. The police as a system or group seem to interact with crime as a system in the process of regulating it. Examples of how these mutually interpenetrating systems operate were noted recently by a grand jury in Kansas City, which accused the police of cooperating with criminal elements, giving them a monopoly over local crime in return for assistance in controlling disruptive criminal activities. In Denver, the absence of a strong criminal system seems to have contributed to the openly criminal activities of the police: police salaries were not supple-

10 Op. cit. supra note 6.

11 William Foote Whyte, Street Corner Society (Chicago: University of Chicago Press, 1955). 
mented by illegal gratuities, and the police excursion into criminal activities was not countered by entrenched organized criminal interests. In other cities, organized crime actually seems to regulate police activities, keeping them relatively honest.

It is probably useful to view policecriminal behavior from a sociological perspective of intergroup relations. The police and criminal systems represent conflict groups, each trying to regulate the behavior of the other. This process is mediated by a variety of middlemen - bondsmen, lawyers, marginal criminal elements, ex-policemen, judges, politicians, or, as the California crime commission stated in 1950 , by some of the "more respectable members of society." The public becomes aware of this interaction through its most common manifestations: graft, corruption, and the payoff.

If this intergroup perspective is tenable, it follows that the way and the extent to which the two groups are organized will affect the course of their mutual relations. Put in another way, the organization of crime affects those groups charged with controlling it. This means that an understanding of the organization and operation of crime is necessary for a full understanding of the actual performance of police departments. An understanding of other organizations in the community is also necessary for an understanding of police departments.

However, the merging of this double perspective from which departments and their environments have been viewed raises a crucial question. If the effectiveness of police departments is so heavily influenced by the organization of the community, other legal and quasi-legal agencies, politicians, city administrations, and the criminal world itself, is it possible that departments can by their own independent efforts become more effective in their campaign against organized crime? Or, given this interorganizational system which we have pictured, is greater police effectiveness dependent on a balanced program of reform of all the relevant social actors in this social system? More specifically, what independent influence can an internal reorganization of a police department have upon the obstacles to effectiveness raised by the outside community? These questions have in the past been the concern primarily of policy-makers, as suggested in the earlier mentioned ideological conflict between groups which adhere to the beehive theory of police work and those who direct their primary attention to eliminating the causes of crime. On the other hand, it has been our argument that greater attention should be given to reforming police departments internally so that they can cope more effectively with the external obstacles created by groups in the larger.community.

\section{Ineffectiveness and Democracy}

Much of the social science literature on crime and, especially, juvenile delinquency, refers to deviant subcultures. Cloward and Ohlin concern themselves specifically with how delinquent subcultures are created, sustained, and, possibly, transformed.12 One might also expect that ineffective, corrupt police departments would have characteristically antisocial, deviant cultures. For example, the members of such departments might ad-

12 Richard Cloward and Lloyd Ohlin, Delinquency and Opportunity (New York: Free Press, 1960). 
here to life philosophies which hold that man is inherently evil, that he is not to be trusted, that he must be held responsible for all his actions, that the wrongdoer is incapable of being reformed, and that physical force and coercion are the only worthwhile tools the policeman has - all views which may contribute to the control of crime but which at the same time contravene many honored American values. One might also expect the members of such departments to place little value on strict adherence to the law and to believe that deviation is normal and therefore not deviant, that there is no reason to expect the police to act any differently from the rest of the normally corrupt society, and that life is a gamble, requiring risks but also affording opportunities for personal profit - all views which encourage poor police performance.

However, it is important to distinguish corruption from ineffectiveness. Police departments with identical cultures can differ greatly from one another simply because of the different ways they are organized. Of course, some departments are so ill-adapted to their environments that pressures are created which lead almost inevitably to a socially undesirable culture completely at odds with the publicly stated goals of the police. But, if studies of industrial, medical, military, and other organizations have any relevance to police organizations, we would expect that the way a department is organized will affect the stresses which its members feel in their occupational roles and also the ways in which they react to these stresses. When the stresses are of a certain kind, and when they are distributed in a certain pattern within the department, ineffectiveness and possibly corruption will be the product.

It is dangerous to assume, as so many human relations experts do, that stress is necessarily undesirable and that organizations should be internally re-arranged in order to relieve any personal frustrations which employees experience in the course of fulfilling their job responsibilities. On the contrary, the viability of other features of American life may depend on the continued relative ineffectiveness of police departments and the perpetual frustration of policemen. Re-organization for complete effectiveness in the fight against crime might place the police in a position where they can easily violate many constitutionally guaranteed rights. This is a danger to which we must be alert, but it should not be allowed to delay overdue efforts to discover ways to increase the effectiveness of this significant sector of American governmental operations. 